\title{
Determinants of Participation in Farmers Training Centre Based Extension Training in Ethiopia
}

https://dx.doi.org/10.4314/jae.v25i2.8

\author{
Abera Alemu \\ Department of Rural Development and Agricultural Extension, Faculty of Environment \\ Gender and Development Studies, College of Agriculture, Hawassa University, Ethiopia \\ E-mail: abrish8353@gmail.com; +251-916038353
}

\begin{abstract}
The study assessed the determinants of farmers' participation in farmers training center based trainings and its outcome on maize, haricot bean and coffee productivity. Data were collected from randomly selected 194 households. Outcomes of the FTC based training on maize, haricot bean and coffee productivity was analyzed using t-test whereas binary logistic regression model was used to identify factors determining farmers' participation in FTC based training. The result showed that education, land size, contact with development agent, access to road, wealth status and livestock holding of the household positively determine households' decision to participate whereas distance from FTC negatively determines households' decision to participate. There was positive outcome of the FTC based training on maize, haricot bean and coffee productivity. The study recommends that governmental, public and private sectors should expand access to education, access to road and strength linkage between famers and agricultural development agents.
\end{abstract}

Keywords: Farmers training centers, crop productivity.

\section{Introduction}

For decades, successive Ethiopian governments have invested substantial resources in agricultural extension, specifically in training and employing extension staff, infrastructural development such as building the Farmers Training Centers (FTC) and strengthening agricultural research (Leta, 2018). The basic objective behind this huge investment is to enhance farmers' knowledge, disseminate new technology, which are needed to increase agricultural productivity and thereby to develop rural areas where majority of the country's population live. Agricultural development agents are responsible to fill skill and knowledge gap of the farmers by transferring knowledge and technologies developed in agricultural research systems through provision of both practical and theoretical training at FTC (Leta, 2019).

In Ethiopia FTC are constructed in every Kebele, the lowest administration unit, with the main aim of transferring new technology, providing training and experience sharing. The training is usually provided by development agents recruited at each FTC. Usually, three extension agents including crop production, natural resource management and animal health experts provide timely training to the farmers based on the farmers need. Accordingly, FTC-based farmer training is the currently implemented extension strategy geared towards human capital development through need-based, hands-on practical training that aim to facilitate agricultural 
Creative Commons User License: CC BY-NC-ND

Abstracted by: EBSCOhost, Electronic Journals Service (EJS),

Google Scholar, Journal Seek, Scientific Commons,

Food and Agricultural Organization (FAO), CABI and Scopus
Journal of Agricultural Extension

Vol. 25 (2) April, 2021

ISSN(e): 24086851; ISSN(Print); 1119944X

http://journal.aesonnigeria.org

http://www.ajol.info/index.php/iae

Email: editorinchief@aesonnigeria.org

transformation and rural livelihood improvement. In fact, farmer training centers serve as the cornerstone of Ethiopia's strategy that supports the transformation of small-scale farming into business-oriented activities (Luchia, 2015).

Considering the agricultural seasons, there are two types of training that are offered to farmers at FTCs. These are short-term and modular training. The first type is delivered to 15-20 farmers for 3-20 days on the demonstration plots of the FTCs or on the fields of model farmers. The commencement of modular training considers 20-30 individual farmers in order to reduce the adverse effect of group size and enhance the retention capacity of the farmers on different training packages. The major key agricultural service provided with $80 \%$ practical and $20 \%$ theoretical ratio includes agronomic practices of various crops considering their agro ecology, animal husbandry and health, and natural resource management and conservation. The duration of modular training provided in each subject is 3-6 months. Depending on the type of the subject, two training periods can be arranged each year. Each trainee is expected to attend two days/week ( 6 hours per day, of which 2 hours for theory and 4 hours for practical part). This means, a total of 300 hours of participation in the training is required to graduate with a "Green Certificate." However, there is flexibility in terms of training hours based on the particular context where the training is organized. The training methodologies employed by FTCs include: class room lecture, demonstration trial, field practice, exposure visit, and rural radio programme (Muluken et al., 2017).

Recent studies (Anne, 2018; Leta, 2018; Wordofa and Sassu, 2018; Meja and Geta, 2017; Leta, 2017; Elias, et al 2015; Simpson, 2015) conducted in FTC based extension system gave more emphasis on assessing problems hindering functionality of FTC, impact of FTC on income and providing general agricultural extension system overview of Ethiopia. However, the premising gap of these studies is they didn't study about determinants of farmers' participation in FTC based trainings and its potential outcome on agricultural productivity. Hence, to fill these recent literature gaps, this study was conducted focusing on two specific objectives. The first specific objective was to examine determinants of farmers' participation in farmers training center based trainings; the second specific objective was to examine the outcomes of farmers training center based extension training on maize, haricot bean and coffee productivity.

\section{Methodology}

Aleta chuuko Woreda is located in Sidama regional state within $6^{\circ} 27^{\prime} 20^{\prime \prime} E$ $6^{\circ} 40^{\prime} 14^{\prime \prime} \mathrm{N}$ Latitude and $38^{\circ} 12^{\prime} 31 \mathrm{E}-38^{\circ} 25^{\prime} 33^{\prime \prime} \mathrm{E}$ Longitude. The Woreda is situated $338 \mathrm{~km}$ south of Addis Ababa, capital of Ethiopia and $66 \mathrm{~km}$ south of Hawassa, capital of Sidama region. It is bordered on south by Dara district, on south west by Oromia region, on the west by Loka Abaya district, on the north by Dale district, and the east by Aleta Wondo district. The Woreda consists of 26 administrative rural and 4 urban Kebeles (the smallest or local administrate unit) and has an area of 32,248 hectares. Based on the 2007 Census and projections in 2019/20 Woreda population size estimated to be 301,012 , of which 147496 are male and 153516 female with 
Creative Commons User License: CC BY-NC-ND

Abstracted by: EBSCOhost, Electronic Journals Service (EJS),

Google Scholar, Journal Seek, Scientific Commons,

Food and Agricultural Organization (FAO), CABI and Scopus
Journal of Agricultural Extension

Vol. 25 (2) April, 2021

ISSN(e): 24086851; ISSN(Print); 1119944X

http://journal.aesonnigeria.org

http://www.ajol.info/index.php/jae

Email: editorinchief@aesonnigeria.org

population density of 681 persons per square kilometer. The total number of households is 60202 with the average family size of 5 persons. The altitude of the Woreda ranges between 1,400-2,300 meters above sea level. The common crops grown in the Woreda are Enset (false banana), coffee, maize, chat, avocado, mango, pineapple, banana and sweet potato. Enset is the main staple food for the rural population of the Woreda.

Multi-stage sampling procedure was followed to select sample households. In the first stage, the study district was selected. In the second stage 4 Kebeles were selected randomly among 16 Kebeles having functional FTCs. In the third stage within the selected 4 Kebeles households were stratified into two including those who have received FTC based training for the last 5 years and those who haven't received any trainings. Study population was farmers who are the residences of the sampled Kebeles. Following, a sample size for this study was determined by using Yamane (1967) sample determination formula at precision level 7\%. Based on this the total sample size of the study was 194 households. Respective sample for each categories (trained and non-trained) was determined based on proportion to the population size. Accordingly, among 194 total households 58 of them were trained on different agricultural production techniques by development agents at FTC and 136 were non-trained households. Finally representative samples from each Kebeles was selected by using simple random sampling through lottery methods.

$$
n=\frac{N}{1+N\left(e^{2}\right)}
$$

Where, $\mathbf{n}=$ sample size, $\mathbf{N}=$ population size, $\boldsymbol{e}$ is level of precision.

$$
\boldsymbol{n}=\frac{3800}{1+3800\left(0.07^{2}\right)} \quad \boldsymbol{n}=194
$$

Both open ended and close ended questions were prepared to collect primary data from the respondents. Data was edited and made ready to data entry. Determinants of farmers' participation in FTC based training was analyzed using binary logistic regression. Besides, independent t-test was applied to compare the annual crop productivity between trained and non-trained farmers. Productivity was measured by dividing the total production to the land size measured in hectare where the production come from.

Binary logistic regression model was used to identify determinants of farmers' participation in FTC based training. Such a model is appropriate if participation fits into a dichotomous choice, essentially taking on values of zero and 1 (i.e. whether a respondent participates or does not participate in a particular activity or set of activities). Dependent variable and independent variables used in the model are presented on Table 1.

The model can be specified as 
Creative Commons User License: CC BY-NC-ND

Abstracted by: EBSCOhost, Electronic Journals Service (EJS), Google Scholar, Journal Seek, Scientific Commons,

Food and Agricultural Organization (FAO), CABI and Scopus
Journal of Agricultural Extension

Vol. 25 (2) April, 2021

ISSN(e): 24086851; ISSN(Print); 1119944X

http://journal.aesonnigeria.org

http://www.ajol.info/index.php/jae

Email: editorinchief@aesonnigeria.org

$\operatorname{Prob}(Y i=1)=P i=F(Z i)=F\left(\propto+\sum \beta i X i\right)=\frac{1}{1+\varepsilon-Z i}$

$---1$

Where $\mathrm{Pi}$ is the probability that a farmer participates in the FTC based extension training; Xi represents explanatory variables; and $\alpha$ and $\beta$ are parameters to be estimated.

$\operatorname{Prob}(Y i=0)=1-\operatorname{Prob}(Y i=1)=(1-P i)=\frac{1}{1+8^{z i}}$

$--2$

From Equations (1) and (2), we get,

$\frac{\operatorname{Prob}(Y i=1)}{P_{\text {rob }(Y i=0)}}=\frac{P \tilde{i}}{1-P i}=e^{z i}$

$--3$

where $\mathrm{Pi}$ is the probability that $\mathrm{Yi}$ takes the value 1 and then $(1-\mathrm{Pi})$ is the probability that

$\mathrm{Yi}$ is 0 and $\mathrm{e}$ is the exponential constant.

Now taking the natural log of both sides of Equation (3), we get,

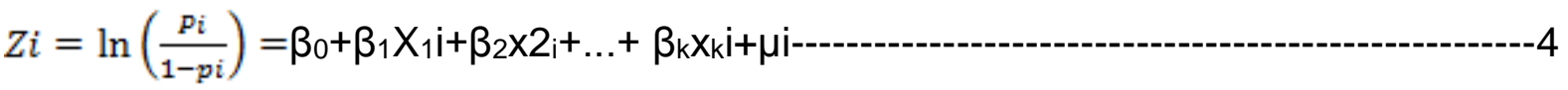

Table 1:. Description of variables used in the logit model

Variable description and measurement

Age of the respondents measured in years

Sex of the household head ( 0 for female and 1 for male)

Educational attainment of the respondents in years

Agricultural land holding of the respondents in hectare

Annual contact made with agricultural development agents in number

Distance from respondents residence to farmers training center in $\mathrm{Km}$

Access to all weather road ( 1 for who have access and 0 otherwise)

Relative wealth status of the respondents ( 1 for better off and 0 for poor)

Livestock holding of the respondents in Tropical Livestock Unity 
Creative Commons User License: CC BY-NC-ND

Abstracted by: EBSCOhost, Electronic Journals Service (EJS),

Google Scholar, Journal Seek, Scientific Commons,

Food and Agricultural Organization (FAO), CABI and Scopus
Journal of Agricultural Extension

Vol. 25 (2) April, 2021

ISSN(e): 24086851; ISSN(Print); 1119944X

http://journal.aesonnigeria.org

http://www.ajol.info/index.php/jae

Email: editorinchief@aesonnigeria.org

\section{Results and Discussion}

\section{Characteristics of respondents}

It was found that $86.21 \%$ and $58.82 \%$ of trained and non-trained farmers had access to all weather road respectively. This indicate that participants in the FTC based training have relatively better access to road. This helped them travel easily to attend the training even during rainy season. The result further shows that $63.79 \%$ of trained farmers are better off in their wealth status whereas only $43.38 \%$ of nontrained household fall in this category.

Table 2: Distribution of respondents by socio-economic characteristics

\begin{tabular}{|c|c|c|c|c|c|c|c|}
\hline \multirow[t]{2}{*}{ Variables } & \multicolumn{2}{|c|}{ Trained } & \multicolumn{2}{|c|}{ None trained. } & \multicolumn{2}{|c|}{ Total household } & \multirow[t]{2}{*}{ t-test/Chi ${ }^{2}$} \\
\hline & $\begin{array}{l}\text { Percent } \\
(\%)\end{array}$ & Mean & $\begin{array}{l}\text { Percent } \\
(\%)\end{array}$ & Mean & $\begin{array}{l}\text { Percent } \\
(\%)\end{array}$ & Mean & \\
\hline Road access & & & & & & & $13.79^{\star \star \star}$ \\
\hline Yes & 86.21 & & 58.82 & & 67.01 & & \\
\hline $\begin{array}{l}\text { Wealth } \\
\text { status } \\
\text { Poor }\end{array}$ & 36.21 & & 56.62 & & 50.52 & & $6.77^{\star \star *}$ \\
\hline Better off & 63.79 & & 43.38 & & 49.48 & & \\
\hline Age & & 46.50 & & 47.88 & & 47.46 & 1.09 \\
\hline Education & & 2.48 & & 1.18 & & 1.56 & $3.65^{\star * *}$ \\
\hline Land & & 0.737 & & 0.615 & & 0.615 & $3.67^{* \star *}$ \\
\hline $\begin{array}{l}\text { Development } \\
\text { agent contact }\end{array}$ & & 3.67 & & 2.22 & & 2.65 & $6.09^{* * *}$ \\
\hline $\begin{array}{l}\text { Farm training } \\
\text { center }\end{array}$ & & 3.12 & & 4.95 & & 4.40 & $4.82^{\star \star *}$ \\
\hline Livestock & & 3.30 & & 2.79 & & 2.94 & 1.64 \\
\hline
\end{tabular}

The average land holding of the trained famers was 0.737 hectare and it was 0.615 hectare for non-trained households, which was significant at $1 \%$. This imply that participation in FTC based training is directly correlated with land holding because the more land size the more production need arise from the farmers. To get better production from large farm land farmers seek knowledge and skill and interested to participate in FTC based training.

Agricultural development agents are experts who are in charge of providing different agriculture related training at FTC for farmers and provide also technical support by visiting farmers farm plots. As shown on Table 2, the average number of contacts made by trained group was 3.67 while it was 2.22 for non-trained. This may indicate 
Creative Commons User License: CC BY-NC-ND

Abstracted by: EBSCOhost, Electronic Journals Service (EJS),

Google Scholar, Journal Seek, Scientific Commons,

Food and Agricultural Organization (FAO), CABI and Scopus
Journal of Agricultural Extension

Vol. 25 (2) April, 2021

ISSN(e): 24086851; ISSN(Print); 1119944X

http://journal.aesonnigeria.org

http://www.ajol.info/index.php/jae

Email: editorinchief@aesonnigeria.org

that farmers who had more contact with development agent were more participants in the FTC based training than the others.

It was found that on average non-trained households were located $4.95 \mathrm{~km}$ far from FTC and that of trained need to travel $3.12 \mathrm{~km}$ to reach to the FTC. The result of $\mathrm{t}-$ test analysis reveals that there was statistically significant difference between two groups in terms of distance from their residence FTC at $1 \%$ significance level. This may indicate that relatively trained households found near to FTC than the nontrained household which may be one factor that affects non-participants to attend training regularly.

\section{Determinants of Farmers' Participation in FTC Based Training}

This section presents the output of binary logistic regression implemented to analyze determinants of farmers' participation in FTC based training. Nine variables were hypothesized which are assumed to affect farmers' participation in FTC based training. Among them, seven were found to be significant while the rest two variables were insignificant in explaining the variations in the dependent variable. The result of the logit regression analysis (Table 3 ) shows that education, land size, contact with development agent, access to road, wealth status and livestock holding determine households' participation in FTC based trainings positively at different degree of significance level. A positive relationship between education and FTC based training may show that more educated people are more adopter of technology than others and able to understand and apply different sort of training provided in FTC which helps them to attend the training regularly. This is consistent with the study conducted by (Muhammad, 2020; Danso-Abbeam et al., 2017; Kadafur et al., 2017; Mmbando \& Baiyegunhi, 2016; Salifu \& Salifu, 2015). Moreover, it was found that a one contact made with development agent increases the probability of participation in FTC based training by 1.5 units keeping the other factors constant. A positive relationship between contact with development agent and FTC based training participation also shows that farmers who have more contact with development agent are more aware about the FTC including what sort of trainings are provided there with their outcomes than the others. This is consistent with (Kadafur et al., 2017 and Abbeam et al., 2017). 
Creative Commons User License: CC BY-NC-ND

Abstracted by: EBSCOhost, Electronic Journals Service (EJS),

Google Scholar, Journal Seek, Scientific Commons,

Food and Agricultural Organization (FAO), CABI and Scopus

http://eoi.citefactor.org/10.11226/v25i2
Journal of Agricultural Extension

Vol. 25 (2) April, 2021

ISSN(e): 24086851; ISSN(Print); 1119944X

http://journal.aesonnigeria.org

http://www.ajol.info/index.php/jae

Email: editorinchief@aesonnigeria.org

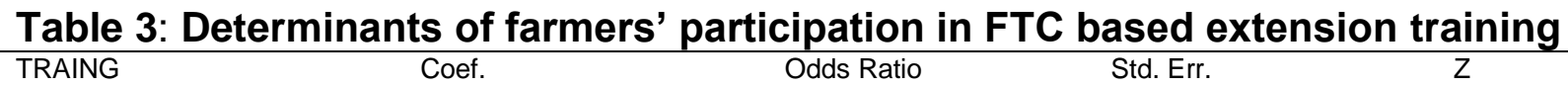

\begin{tabular}{|c|c|c|c|c|}
\hline Age & -0.025 & 0.976 & 0.026 & -0.95 \\
\hline Sex & 0.027 & 1.027 & 0.747 & 0.04 \\
\hline Education & $0.237^{\star * *}$ & 1.268 & 0.087 & 2.73 \\
\hline Land holding & $1.780^{* *}$ & 5.932 & 0.697 & 2.55 \\
\hline $\begin{array}{l}\text { Contact made with } \\
\text { agricultural development } \\
\text { agents }\end{array}$ & $0.409^{\star * \star}$ & 1.506 & 0.138 & 2.96 \\
\hline $\begin{array}{l}\text { Distance from respondents } \\
\text { residence to farmers training } \\
\text { center }\end{array}$ & $-0.196^{\star *}$ & 0.822 & 0.092 & -2.14 \\
\hline Access to all weather road & $1.563^{\star \star *}$ & 4.773 & 0.497 & 3.15 \\
\hline $\begin{array}{l}\text { Relative wealth status of the } \\
\text { respondents }\end{array}$ & $0.684^{*}$ & 1.981 & 0.404 & 1.69 \\
\hline Livestock holding & $0.182^{*}$ & 1.199 & 0.101 & 1.80 \\
\hline _constant & -3.751 & 0.023 & 1.632 & -2.30 \\
\hline
\end{tabular}

$$
{ }^{* * *} \mathrm{P}=0.01,{ }^{* *} \mathrm{P}=0.05
$$

The result of odds ratio shows that access to road favors participation in FTC based training by 4.77 factors keeping the other conditions constant. Moreover, a positive relationship between access to road and FTC based training show that respondents who have access to all weather road have more chance to attend the FTC based training than the other. Because it helps them to travel easily to attend different training given in FTC even during rainy season. The odds ratio result of the variable land size shows that a one hectare increase in land size increase households' probability of participation in FTC based training by 5.93 units keeping the other factor constant. A positive relationship between FTC based training and land shows that those households who have relatively large land size needs technical knowledge and skill to produce more from their land than the other. Besides, they also need more knowledge to manage their land effectively than the others.

From odds ratio analysis result it was depicted that wealth status favor the probability of participation in FTC based training by a factor of 1.98 units for those households who are economically better off keeping other factors constant. A possible reason for the positive relationship between participation in FTC based training and wealth status is that farmers who are relatively poor are busy with other activities; they look over other livelihood opportunities to meet the immediate demand of their families as they have relatively less land holding; due to this reason they participate in non-farm activities mostly in daily labor activities and their chance to participate in FTC based training is limited.

It was found that a single TLU increase in livestock holding increases the households' probability participation in FTC based training by 1.19 units keeping the other factors constant. A positive relationship between the two variable indicate that 
Creative Commons User License: CC BY-NC-ND

Abstracted by: EBSCOhost, Electronic Journals Service (EJS),

Google Scholar, Journal Seek, Scientific Commons,

Food and Agricultural Organization (FAO), CABI and Scopus
Journal of Agricultural Extension

Vol. 25 (2) April, 2021

ISSN(e): 24086851; ISSN(Print); 1119944X

http://journal.aesonnigeria.org

http://www.ajol.info/index.php/jae

Email: editorinchief@aesonnigeria.org

farmers who have large livestock have high probability to come to FTC and attend training because they need both practical and theoretical knowledge to manage their livestock to get better production. This finding is consistence with (Temesgen et al, 2015).

A negative relationship between FTC based training and distance to FTC shows that famers who are relatively far from the FTC are less participant in FTC based extension because it takes their time, energy and additional cost to travel there. The odds ratio of this variable indicate that a one kilometer increases in FTC distance from respondents residence decrease the probability of participation in FTC based training by 0.82 units keeping the other factors constant.

\section{Outcomes of FTCs on Selected Crop Productivity}

The mean maize productivity in hectare for FTC based extension service participant households was 60.84 quintals and that of non-participants was 44.74 quintals. The mean difference was was statistically significant difference between the participant and non-participant households in term of maize productivity at $1 \%$ significance level. This finding is similar with a study conducted by which concluded the extension program has a positive effect on farm productivity. According to this study extension participation increases farm productivity by $6 \%$ than non-participant households.

Moreover, the result also shows the positive outcome of TFC based training on haricot bean and coffee productivity. Accordingly, it was found that the mean haricot bean productivity of participant group was 16.76 quintals and 13.46 quintals for that of non-participants. The difference (outcome) was 3.3 quintals. Besides, the mean analysis result of the crop coffee also shows that the 2.37 quintals mean difference between the trained and non-trained households. A study conducted by Chenchu et al., (2015) is consistence with the finding of this study. This study had concluded that FTC based training have positive impact on farm productivity. Another study conducted by Gizaw (2018) also showed that the training provided in FTCs helped the farmers to enhance their livelihood by changing their attitude, enabled them to use modern technologies to increase productivity, keep their health and hygiene, for saving, and engaging in cooperatives.

Table 4: Outcomes of FTCs based trainings on crop productivity (quintals/ha)

\begin{tabular}{lcccc}
\hline Crop & $\begin{array}{c}\text { Participants } \\
(\mathrm{n}=58)\end{array}$ & $\begin{array}{c}\text { Non-participants } \\
(\mathrm{n}=136)\end{array}$ & Difference & t-test \\
\hline Maize & 60.84 & 44.74 & 16.10 & $25.68^{* * *}$ \\
Haricot Bean & 16.76 & 13.46 & 3.3 & $9.59^{* * *}$ \\
Coffee & 9.41 & 7.03 & 2.37 & $9.39^{* * *}$ \\
\hline \multicolumn{1}{c}{${ }^{* * *} \mathrm{P}=0.01$} & & & &
\end{tabular}


Creative Commons User License: CC BY-NC-ND

Abstracted by: EBSCOhost, Electronic Journals Service (EJS),

Google Scholar, Journal Seek, Scientific Commons,

Food and Agricultural Organization (FAO), CABI and Scopus
Journal of Agricultural Extension

Vol. 25 (2) April, 2021

ISSN(e): 24086851; ISSN(Print); 1119944X

http://journal.aesonnigeria.org

http://www.ajol.info/index.php/jae

Email: editorinchief@aesonnigeria.org

\section{Conclusion and Recommendations}

Participating in FTCs based training is very crucial for farmers to increases their agricultural production and productivity. This study was conducted to identify the determinants of farmers' participation in FTCs based training and its outcomes on maize, haricot bean and coffee productivity widely grown in the study area. Participation in FTC based training is positively determined by education, land size, contact with development agent, access to road, wealth status and livestock holding and negatively by distance to FTC. Furthermore, it was concluded participation in FTC based training have positive outcome on maize, haricot bean and coffee productivity. On the basis of these empirical findings, the study recommends that expanding access to all weather road for farmers, providing attention to adult education, strengthening linkage between farmers and development agents should be given due attention.

\section{References}

Abdullahi Alhaji Jamilu, Atala T. K, Akpoko J. G and Sanni S. A. (2015). Factors influencing smallholder farmers participation in IFAD-community bBased agricultural and rural development project in Katsina State. Journal of Agricultural Extension. 19(2) 93-105.

Ali Chandio and Yuansheng Jiang (2018). Factors influencing the adoption of improved wheat varieties by rural households in Sindh, Pakistan Abbas. AIMS Agriculture and Food 3(3) 216-228.

Anne M. Cafer and J. Sanford Rikoon, (2018). Adoption of new technologies by smallholder farmers: the contributions of extension, research institutes, cooperatives, and access to cash for improving tef production in Ethiopia. Agriculture and Human Values. $35,685-699$

Chenchu Narayana, Mohammed Abdurahman and Ponduri Suresh, (2015). Impact of training of farmers training centers on farmer's productivity: The case of dire teyara and sofi woredas of Harari Region-Ethiopia. International Journal of Agriculture Innovations and Research 3:2319-1473.

Danso-Abbeam, G., Bosiako, J. A., Ehiakpor, D. S., and Mabe, F. N. (2017). Adoption of improved maize variety among farm households in the northern region of Ghana. Cogent Economics \& Finance 5(1) 1-14.

Daniel Temesgen, Umer Hinde and Jamal Yusuf (2015). Determinants of farm women participation in agricultural extension training programs: A case from selected district of Oromia Region of Ethiopia. International Journal of Agricultural Science Research, 4(4), 067-077.

Elias, M. Nohmi, K. Yasunobu and A. Ishida. (2015). Farmers' satisfaction with agricultural extension service and its influencing factors: A case study in North West Ethiopia. J. Agr. Sci. Tech. Vol. 18: 39-53

Gerba Leta, Girma Kelboro, Kristof Van Assche, Till Stellmacher \& Anna-Katharina Hornidge (2019): Rhetorics and realities of participation: the Ethiopian agricultural extension system and its participatory turns. Critical Policy Studies. pp 1-20.

Gizaw Eshetu, (2018). The Impacts of Farmers Training Centers in Enhancing the Livelihoods of Rural Farmers; the Case of Kutcha Wereda, SNNPR Regional States: A Thesis Submitted to the College of Education and Behavioral Studies Department of Curriculum and Instruction in Partial Fulfillments of the Requirements for the 
Creative Commons User License: CC BY-NC-ND

Abstracted by: EBSCOhost, Electronic Journals Service (EJS), Google Scholar, Journal Seek, Scientific Commons,

Food and Agricultural Organization (FAO), CABI and Scopus
Journal of Agricultural Extension

Vol. 25 (2) April, 2021

ISSN(e): 24086851; ISSN(Print); 1119944X

http://journal.aesonnigeria.org

http://www.ajol.info/index.php/jae

Email: editorinchief@aesonnigeria.org

Degree of Master of Arts in Adult Education and Community Develop, Addis Ababa University

Kadafur, M. I., Idrisa, Y. L., Kamara, A. Y., and Oyinbo, O. (2017). Understanding the drivers of adoption intensity of improved maize varieties in Northern Guinea Savannah of Borno State, Nigeria. Albanian Journal of Agricultural Sciences, 16(2), 59-66.

Leta, G. 2018. The Ethiopian Agricultural Extension System and Its Role as a 'Development Actor: Cases from Southwestern Ethiopia." Dissertation, Center for Development Research (ZEF), University of Bonn.

Leta, G. 2018. The Ethiopian Agricultural Extension System and Its Role as a 'Development Actor': Cases from Southwestern Ethiopia." Dissertation, Center for Development Research (ZEF), University of Bonn.

Leta, G., G. Kelboro, T. Stellmacher, and A.-K. Hornidge 2017. The Agricultural Extension System in Ethiopia-Operational Setup, Challenges and Opportunities. Working paper 158, ZEF Working Paper Series, ISSN 1864-6638.

Luchia Tekle (2015). Analysis of Positive Deviance Farmer Training Centers in Northern Ethiopia. American Journal of Rural Development 3: 10-14.

Merihun Fikru Meja and Endrias Geta (2017) Analyzing Farmers' Trining Centers through Integrated Innovative Capacity Building and Technologies Transfer; A Case Study of Damot Gale District Woliata Zone Ethiopia. International Journal of Environmental Sciences 6:94-100

Muddassir, Muhammad, Al Shenaifi, Mohamed Saleh, Kassem, Hazem Salah and Alotaibi, Bader Alhafi (2020). Adoption of Improved Maize Production Technologies in Punjab Province, Pakistan. Journal of Agricultural Extension, 24 (2), 1-11.

Muluken Gezahegn Wordofa and Maria Sassi (2018). Impact of farmers' training centres on household income: Evidence from propensity score matching in Eastern Ethiopia. Social Science, 7(4), 1-12.

Simpson, Brent. 2015. Planning for scale: Using what we know about human behavior in the diffusion of agricultural innovation and the role of agricultural extension. USAID, MEAS. available at: https://www.agrilinks.org/sites/default/files/resource/files/MEAS\%20TN\%20Scaling\% 20-\%20Brent\%2C\%20Simpson\%20-\%20March\%202015_0.pdf 